\title{
ALGUMAS REFLEXÕES SOBRE A PANDEMIA, AS VISIBILIDADES, A VELOCIDADE E SUSPENSÕES POSSÍVEIS EM UMA EXPERIÊNCIA AUDIOVISUAL DOCENTE
}

\author{
SOME REFLECTIONS ABOUT THE PANDEMIC, THE VISIBILITY, SPEED AND POSSIBLE \\ SUSPENSIONS IN AN AUDIOVISUAL TEACHER EXPERIENCE
}

\author{
ALGUNAS REFLEXIONES SOBRE LA PANDEMIA, LA VISIBILIDAD, VELOCIDAD Y \\ POSIBLES SUSPENSIONES EN UNA EXPERIENCIA DE PROFESOR AUDIOVISUAL.
}

Bruno Teixeira Paes ${ }^{1}$; Adriana Fresquet ${ }^{2}$

\begin{abstract}
RESUMO
A proposta deste artigo é oferecer um mapeamento a respeito de certos impactos sociais, culturais, econômicos, psicológicos e pedagógicos da pandemia de covid-19 e, dentro desse cenário, pensar de que modo uma proposta de experiência audiovisual pode contribuir para o processo pedagógico de compreensão deste momento. Algumas formas autônomas de trabalho ganharam força e disseminação em meio ao isolamento forçado. Termos como home office, 'teletrabalho', 'ensino remoto', 'cursos online', palestras, webinars, 'startups de inovação digital' e outras narrativas ganharam força. Em um contexto de afastamento social, os professores enfrentaram desafios e buscaram soluções para encontrar uma sobrevivência. Em meio a todas essas implicações e agenciamentos colocados por essa realidade ao espaço da escola e às subjetividades profissionais de docentes (e discentes) atravessados pelas visibilidades, pelos recursos midiáticos e pelas novas temporalidades, precisamos compreender um pouco sobre o impacto de certos comportamentos neste novo contexto social. Nesse sentido, compartilhamos uma experimentação audiovisual em estágio inicial, realizada via telefone celular em uma turma de ensino fundamental. A proposta é a produção de pequenas 'videocartas pandêmicas' que captem planos, imagens, objetos, rotinas, histórias ou momentos que, na visão do aluno, sejam ilustrativos de uma emoção e/ou reflexão sobre estes tempos de distanciamento. Concluímos que os processos audiovisuais configuram uma maneira ampla e plural que conjuga diversas linguagens no ato de comunicar o pensamento, sensível em um contexto de audiovisualização da vida.
\end{abstract}

PALAVRAS-CHAVE: Sociedade. Pandemia. Covid-19. Educação. Tecnologias. Audiovisual.

\footnotetext{
${ }^{1}$ Doutor em Educação - Universidade Federal do Rio de Janeiro (UFRJ). Rio de Janeiro, RJ - Brasil. Foi Professor substituto concursado do curso de Licenciatura em cinema e vídeo - Universidade Federal Fluminense (UFF). Niterói, RJ - Brasil. E-mail: bruno.paes@gmail.com

${ }^{2}$ Doutorado em Ciências Psicopedagógicas - Faculdade de Humanidades e Ciências da Educação - Pontifícia Universidade Católica Argentina. Santa Maria de los Buenos Aires. Buenos Aires - Argentina. Professora associada - Faculdade de Educação - Universidade Federal do Rio de Janeiro (UFRJ). Rio de Janeiro, RJ - Brasil. Membro do Programa de Pós-Graduação em Educação (FE/UFRJ). Rio de Janeiro, RJ - Brasil. E-mail: adrianafresquet@gmail.com
}

Submetido em: 18/06/2021 - Aceito em: 19/11/2021

(C) ETD-Educação Temática Digital Campinas, SP $\quad$ v.24 $\quad$ n.1 $\quad$ p. 53-70 jan./abr. 2022




\section{ABSTRACT}

The purpose of this article is to provide a mapping of certain social, cultural, economic, psychological and pedagogical impacts of the Covid-19 pandemic and, within this scenario, to think about how a proposal for an audiovisual experience can contribute to the pedagogical process of understanding this moment. Some autonomous forms of work gained strength and spread amid forced isolation. Terms such as home-office, telework', remote learning', 'online courses', lectures, webinars, 'digital innovation startups' and other narratives gained traction. In a context of social distancing, teachers faced challenges and sought solutions to find survival. And, amidst all these implications and arrangements placed by this reality on the school space, on the professional subjectivities of teachers (and students) crossed by visibilities and media resources and new temporalities, we need to understand a little about the impact of certain behaviors in this new social context. In this sense, we share the first steps of an audiovisual experimentation carried out via cell phone in an elementary school class. The proposal is the production of small 'pandemic video-letters' that capture plans, images, objects, routines, stories, moments that, in the student's view, would be illustrative of an emotion and/or reflection of these times of distancing. Our point is to show that audiovisual processes constitute a broad and a plural way that combines several languages in the act of a thought communication. Sensitive in one context of a life audiovisualization.

KEYWORDS: Society. Pandemic. Covid-19. Education. Technologies. Audiovisual aids.

\section{RESUMEN}

El propósito de este artículo es brindar un mapeo de ciertos impactos sociales, culturales, económicos, psicológicos y pedagógicos de la pandemia Covid-19 y, dentro de este escenario, pensar cómo una propuesta de experiencia audiovisual puede contribuir al proceso pedagógico. de entender este momento. Algunas formas autónomas de trabajo cobraron fuerza y se extendieron en medio del aislamiento forzado. Términos como oficina en casa, trabajo a distancia ", aprendizaje remoto", "cursos en línea", conferencias, seminarios web, "empresas emergentes de innovación digital" y otras narrativas ganaron terreno. En el contexto del aislamiento social, los maestros enfrentaron desafíos y buscaron soluciones para encontrar una supervivencia. $Y$, en medio de todas estas implicaciones y arreglos que coloca esta realidad en el espacio escolar, en las subjetividades profesionales de los docentes (y discentes) atravesados por visibilidades y recursos mediáticos y nuevas temporalidades, es necesario comprender un poco el impacto de determinadas conductas en este nuevo contexto social. En este sentido, compartimos la experimentación audiovisual realizada a través del teléfono celular en una clase de primaria. La propuesta es la producción de pequeñas 'video-cartas pandémicas' que capturan planos, imágenes, objetos, rutinas, historias, momentos que, a juicio del alumno, serían ilustrativos de una emoción y / o reflejo de estos tiempos lejanos. Concluimos que los procesos audiovisuales constituyen una forma amplia y plural que combina varios lenguajes en el acto de comunicar el pensamiento. Sensible en uno contexto de audiovisualización de la vida.

PALAVRAS-CLAVE: Sociedad. Pandemia. Covid-19. Educación. Tecnologías. Audiovisual. 


\section{INTRODUÇÃO: PRIMEIRAS REFLEXÕES SOBRE A ‘SUSPENSÃO’ DAS ROTINAS}

A proposta deste artigo é oferecer uma espécie de mapeamento de certos impactos sociais, culturais, econômicos, comportamentais e pedagógicos da pandemia de covid-19 e, dentro desse cenário, pensar de que modo uma proposta inicial de experiência audiovisual, que surge da percepção de uma professora no contexto da educação remota, pode contribuir para o processo pedagógico ${ }^{3}$ de compreensão deste momento.

Em mais de um ano e meio nessa situação, atravessamos uma estranha sensação de suspensão de tempos (do fazer, do lazer, dos afetos, dos trabalhos etc.). Nesse contexto, um movimento de produção continuada de novas formas de trabalho acabou se impondo sobre todos nós; algo que, de certa forma, nos convoca a encontrar soluções pragmáticas de subsistência (e sobrevivência) em meio aos diferentes pontos de reflexão, angústia e transformação.

Interessante notar que, após quase dois anos nesta estranha suspensão, muito foi pensado e problematizado no âmbito da produção intelectual e profissional. É possível recordar que, nas primeiras semanas, quando assistíamos, pelos veículos de comunicação, ao impacto social da primeira onda crítica de perdas de vidas na Europa, enquanto víamos suas ruas vazias e comércios fechados, muitos apontaram que aquele seria um momento para se repensar os rumos e as velocidades que o mundo capitalista estava tomando. Era a chance que a civilização tinha para pensar sobre seus atos e seu relacionamento com o planeta.

A breve suspensão deu uma espécie de respiro à natureza. Vimos um pouco de céu azul na acinzentada China. Golfinhos ocuparam os fétidos canais de Veneza. Cabras montanhesas caminhavam tranquilas pelas ruas do País de Gales. Confinados em nossos apartamentos, tivemos tempo para pensar em coisas, reinventar e descobrir outras habilidades. No início, foram as tentativas de aprendizados culinários. Alguns começaram a explorar as redes sociais e a produção de vídeos como estratégias de diálogo, 'mensagens em garrafas virtuais' visando a construir pontes com outras subjetividades solitárias. Outros, para afagar o tédio e a solidão de si e dos seus próximos, faziam performances nas sacadas de suas casas. Além disso, corais musicais foram formados, apresentações de dança e coreografias em lotes vazios foram realizadas para uma plateia em clausura. Essas e outras inúmeras estratégias foram criadas como aproximações de afeto. As tecnologias auxiliaram na manutenção de certo grau de sanidade (o que acabou promovendo uma estafa mental, mas falaremos sobre isso adiante). Em meio a reuniões com amigos, familiares e festas solitárias

\footnotetext{
${ }^{3}$ As contribuições e depoimentos que serviram de inspiração para algumas destas reflexões foram levantados por professores que atuam na educação básica e que integram o grupo de pesquisa de extensão de uma instituição de ensino superior, além do contato com professores que estão atuando no ensino remoto da educação básica de uma escola particular de classe média baixa da cidade de Belo Horizonte.
}

$\begin{array}{llllll}\text { (C) ETD-Educação Temática Digital } & \text { Campinas, SP } & \text { v.24 } & \text { n.1 } & \text { p. } 53-70 & \text { jan./abr. } 2022\end{array}$


virtuais, as telas assumiram outros protagonismos. Brindávamos cercados pela confusão das janelas dos Zoom's, Jitsi's, Google meet's ${ }^{4}$. As falas se atropelam, as janelas congelam, os fundos de tela divertidos tentam criar um clima de informalidade. Algo próximo a tudo isso foi a tônica durante os primeiros dias, quando achávamos que a ideia de quarentena iria durar, no máximo 'quarenta dias'.

No início de todo esse contexto, não foram poucos os que tentaram entender, no calor do momento, o que se passava na civilização. Filósofos, pensadores, sociólogos, antropólogos produziram, 'a toque de caixa', reflexões sobre este novo momento. Os primeiros textos que foram compartilhados encontram-se em uma compilação de breves ensaios sobre a pandemia, de meados de março de 2020, chamado Sopa de Wuhan ${ }^{5}$. Nessa publicação, há textos dos mais variados pensadores contemporâneos, como Slavoj Zizek, Judith Butler, Paul Preciado, Giorgio Agamben, David Harvey, dentre outros.

Como toda produção desse perfil, várias foram as reflexões que buscaram esclarecer questões sobre as implicações do impacto pandêmico global. Ao fazermos uma releitura de algumas dessas produções, principalmente depois de tanto tempo nesta situação, podemos colocar toda aquela problemática inicial em nova perspectiva. Interessante perceber como cada um analisou e construiu possíveis caminhos para os futuros impactos comportamentais, econômicos e culturais dessa suspensão forçada das rotinas.

O filósofo esloveno Zizek (2020) alertava sobre o risco de que, com a disseminação contínua do vírus, outras epidemias (estas agora ideológicas) poderiam ganhar espaço no campo do discurso. Teorias da conspiração, explosões de preconceito, de racismo e fake news encontrariam um sistema imunológico social fragilizado, o que requereria uma contraforça: um esforço geral para se repensar nossa sociedade, para além dos Estados-Nação. Zizek apostava na necessidade de fazer nascer uma sociedade alternativa, alicerçada em novas formas de solidariedade e cooperação global, uma espécie de reinvenção do comunismo com base na confiança nas pessoas e na ciência. Vale lembrar esse mesmo otimismo do filósofo quando ele discursou ${ }^{6}$ na praça onde estavam os representantes dos 99\%, em 2011, em Wall Street, no movimento conhecido como Occupy. Zizek acreditava que, depois das revoluções coloridas iniciadas no mundo árabe, o levante popular de indignação com o capitalismo no coração do sistema provocaria mudanças substanciais em nossas formas de vida. Porém,

\footnotetext{
${ }^{4}$ Os termos aqui utilizados se referem a plataformas digitais de videoconferência. As três citadas foram as mais utilizadas durante o período pandêmico e assumiram importante relevância nas relações sociais estabelecidas no cenário de confinamento e distanciamento.

${ }^{5}$ Disponível em: https://tuxdoc.com/download/sopa-de-wuhan-em-portugues pdf. Acesso em: 15 mar. 2021.

${ }^{6}$ Disponível em: https://zizek.uk/zizek-at-occupy-wall-street-transcript/. Acesso em: 10 mar. 2021.
}

(C) ETD-Educação Temática Digital $\quad$ Campinas, SP $\quad$ v.24 $\quad$ n.1 $\quad$ p. $53-70 \quad$ jan./abr. 2022


grande parte das pautas foi incorporada e comercializada como novos emblemas de rebeldia jovem e de outras alteridades.

Outro ponto de vista, que foi recepcionado de forma bastante polêmica, foi a defesa feita pelo filósofo italiano Giorgio Agamben (2020) de que a pandemia seria uma invenção cujo propósito era aumentar o controle dos aparelhos de Estado sobre as populações (pensando sobre o caso italiano), visando a mantê-las domesticadas, disciplinadas, cativas. 0 filósofo se ampara nos primeiros estudos e levantamentos do centro de saúde italiano sobre a baixa letalidade do vírus. Àquela época, segundo ele, não haveria justificativa epidemiológica para que governos tomassem medidas tão próximas a um novo 'estado de exceção global'. Segundo Agamben (2020, p. 19),

\begin{abstract}
dois fatores podem contribuir para explicar um comportamento tão desproporcional. Primeiro, manifesta-se mais uma vez a crescente tendência de usar o estado de exceção como paradigma normal de governo. 0 decreto-lei imediatamente aprovado pelo governo "por razões de higiene e segurança pública" resulta de fato em uma verdadeira militarização "dos municípios e das áreas em que resulta positiva pelo menos uma pessoa para a qual não se conhece a fonte de transmissão ou, de toda forma, nos quais existe um caso não atribuível a uma pessoa proveniente de uma área já afetada pelo contágio do vírus".
\end{abstract}

A perspectiva - um tanto quanto descrente - do filósofo provocou ruídos em certos cenários acadêmicos, intelectuais e em alguns veículos da grande mídia. O gesto de pensar a dimensão da pandemia como substituta de um espectro de terrorismo latente que mobiliza ações disciplinares governamentais em direção a 'negociar' com a população, em estado coletivo de pânico, mediante a perda voluntária de suas liberdades individuais e a novas formas de controle em prol de uma suposta segurança sofreu críticas frente aos altos índices de perdas humanas, principalmente no contexto italiano.

Uma outra reflexão - um pouco mais centrada - que teve destaque foi promovida pelas análises do historiador israelense Yuval Noah Harari. Na sua percepção, a mobilização global provocada pela epidemia não teria implicações apenas nas formas como organizamos os sistemas de saúde e as políticas públicas, mas também provocaria alterações nos modos como são estruturados os parâmetros econômicos, políticos e sociais, além de nossa relação com novas formas de trabalho a curto prazo. Essas novas estruturas também provocariam reflexões sobre a sociedade de controle e vigilância, o que implicaria o confronto com certos dilemas éticos importantes. O historiador alerta que, em momentos de convulsão social, o maior risco enfrentado não é o vírus, mas os demônios interiores da humanidade: o ódio, a ganância e a ignorância. Podemos reagir à crise propagando ódio (como culpar os estrangeiros e minorias pela pandemia); podemos reagir à crise estimulando a ganância (explorando a ocasião como oportunidade de aumento de ganhos e concentração de renda pelos mais ricos); e podemos reagir à crise disseminando ignorância (espalhando e acreditando em teorias da conspiração). Para Harari (2020), não há necessidade de se

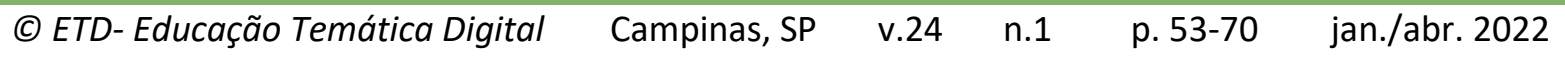


alimentar esses três pilares: Podemos reagir no sentido de gerar compaixão, generosidade e sabedoria: valorizar a ciência, compartilhar, em vez de acumular, e cooperar com o próximo, sem o ver como culpado pela pandemia - como vemos alguns países culpabilizando os chineses como propagadores do vírus.

Grande parte dessas primeiras análises ainda apostava num protagonismo da sociedade e da humanidade como um todo em direção a um processo de autoconhecimento e transformação. Conforme esse tempo de suspensão das rotinas se estendia, percebeu-se que certas apostas e novas posturas (como sempre acontece) foram incorporadas pela roda do sistema de produção. Afinal, essa roda não pode ficar parada por tanto tempo. Algumas formas autônomas de trabalho ganharam força e disseminação em meio ao isolamento forçado. Assim, termos como home office, 'teletrabalho', 'ensino remoto', 'cursos online', palestras, webinars, 'startups de inovação digital' e outras narrativas e ferramentas foram se fazendo cada vez mais presentes e robustas ao longo dos meses. Diante do caos das aulas suspensas de crianças e jovens, o que se viu foram relatos de um agravamento em quadros de depressão e ansiedade, por conta do afastamento social (LINHARES; ENUMO, 2020), quando professores precisavam 'se virar' com telas, programas, salas virtuais, problemas tecnológicos, limitações de equipamentos, angústias de seus alunos, reuniões domésticas de trabalho em meio aos ruídos da vizinhança e às demandas dos filhos sem aula em casa. Face a tamanho caos, ainda fomos soterrados pelo acúmulo de soluções milagrosas trazidas por 'especialistas de ocasião' para o campo da educação e as mais infinitas estratégias de interlocução com os recursos tecnológicos.

\section{BYUNG-CHUL HAN E AS VISIBILIDADES CONTEMPORÂNEAS}

Diante de todas essas implicações e agenciamentos colocados por essa realidade que afeta os espaços da escola, as subjetividades profissionais de professores (e alunos) atravessados pelas visibilidades, pelos recursos midiáticos e pelas novas temporalidades, precisamos compreender um pouco o impacto de certos comportamentos nesse novo contexto social. Sobre isso, o filósofo sul-coreano Byung-Chul Han apresenta duas reflexões bastante interessantes (e provocativas) de análise sobre aspectos dessa sociedade.

A primeira diz respeito a uma "sociedade da transparência" (HAN, 2017), que contempla o avanço de uma perspectiva de positividade em afastamento à dimensão tradicional de negatividade no contexto atual. A positividade é vista aqui como um processo de certa imposição/disposição da sociedade em submeter-se a certas modulações de comportamento em direção a uma constante abertura e horizontalidade das funções pragmáticas, sejam elas sociais, econômicas ou subjetivas. A dimensão de negatividade é aquela mais alinhada às singularidades, ao opaco, aos desejos, à subjetividade. 
Em Sociedade da transparência, Han (2017) aponta que a percepção de transparência na contemporaneidade está bastante alicerçada na ideia da liberdade de informação como exigência e valor inegociável atualmente. Nesse sentido, haveria um processo de desconstrução de uma sociedade da negatividade em direção à valorização absoluta da positividade.

Esses processos vão tornando contextos e situações cada vez mais transparentes, na medida em que é eliminada de si toda e qualquer negatividade, quando as relações se tornam rasas e planas, quando se encaixam sem qualquer resistência ao curso raso do capital, da comunicação e da informação. Analisando os ecos dessa provocação em um contexto de novas práticas de ensino remoto, o que encontramos são relatos de professores, alunos, educadores (e por que não incluir todos os demais profissionais que 'conseguiram' adaptar certa rotina de trabalho para o espaço doméstico por meio do home office?) em uma rotina cada vez mais expositiva. Somos convocados a processos de ensino que se mostram cada vez menos interacionais e mais tutoriais (FRAGA et al., 2021).

Outra dimensão dessa transparência estaria localizada na disputa referente à instância do tempo. Para Han (2017), um tempo transparente é um tempo sem destino e sem evento. É o ápice do movimento sem sentido, em que há uma sobrecarga de imagens e representações límpidas e superexpostas. As imagens são tornadas transparentes e despojadas de qualquer espécie de beleza, de natureza, de coreografia, de cenografia. Toda uma suposta profundidade hermenêutica, todo o sentido possível acaba por tornar-se pornográfico, explícito. Em cumprimento ao status de informação, acabamos por nos integrar a uma dimensão na qual não haveria mediação, apenas um contato imediato entre imagem e olho, pois o sistema social submete todos os seus processos a uma coação por transparência que nivela o próprio ser humano a um elemento funcional de um sistema, que é, por si, violento. As telas das salas de videoconferência expõem o íntimo. Há uma demanda pelas câmeras abertas que invade a dimensão doméstica de outras formas para além do cenário do quarto ou da sala em que estamos. Há uma hierarquização que caminha no subtexto (ou sub hipertexto?) em que esses espaços podem ser 'avaliados' por olhares curiosos e até mesmo julgadores. Em contraposição a isso, está a dimensão de negatividade, a ausência de uma transparência interpessoal, que permite que as performances sociais possam ganhar vida e que mantém vivas as relações.

Mas o que vemos cada vez mais nas transformações das relações e formas de trabalho que estamos sofrendo no atual contexto de pandemia exalta essa dimensão de uma sociedade positiva que repudia qualquer sentimento de negatividade. Em prol de uma lógica de abertura, de desempenho, de velocidade e produtividade, vamos negligenciando as formas de lidar com o sofrimento e a dor. Em meio à velocidade desse 'novo normal', esquecemos como dar forma às singularidades da negatividade. Em matéria publicada pelo

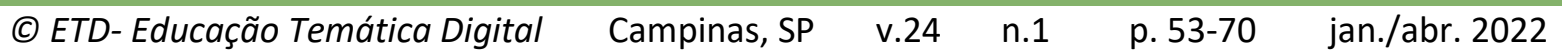


Standford Daily ${ }^{7}$, Nicandro, Khandelwal e Weitzman (2020) destacam o impacto da abertura forçada das imagens nos processos de subjetivação pedagógica dentro do ensino remoto. Eles alertam para os múltiplos motivos que levam os alunos a não habilitarem suas câmeras. Analisando o contexto de alguns professores que compartilharam seus anseios e angústias na rotinas de trabalho remoto, é preciso reconhecer que grande parte dos alunos não possui equipamentos adequados (computadores lentos, internet de baixa qualidade, câmeras de pouca resolução, celulares sem pacote de dados etc.). Outro problema é o ambiente doméstico e a falta de um espaço privado para estudar, além de que, em alguns casos, a exibição do espaço da casa pode provocar constrangimentos com a condição de vida, o que também remete às instâncias de desigualdade.

Assim, a abertura dos espaços domésticos enquanto espaços pedagógicos compartilhados pelos monitores agencia aspectos da sociedade expositiva da transparência (principalmente quando consideramos algumas das práticas profissionais docentes) que imputam uma transformação postural dos sujeitos. Na sociedade expositiva da transparência, cada sujeito é seu próprio 'objeto-propaganda', de forma que tudo é mensurado por seu valor expositivo, e, no caso do ensino remoto, essa exposição também aciona elementos da desigualdade social. É demandado por aqueles que clamam pela maior informatização das ferramentas e metodologias educativas que tudo seja voltado para fora, para a exposição. Mas essa absolutização do valor expositivo das coisas e pessoas se expressa como tirania da visibilidade. A visibilidade é tudo o que a sociedade do espetáculo aponta, e o problemático para o filósofo sul-coreano não é o aumento das imagens em si, mas a "coação icônica" para tornar-se 'imagem': tudo deve tornar-se visível.

Han (2017) traz mais uma provocação interessante para a reflexão, agora acerca do comportamento dos corpos em meio a esse processo de coação para tornar-se imagem, para assumir-se protagonista. Há um quê de obsceno que ronda essa sociedade da transparência, que assume as características de uma sociedade da aceleração. Essa dimensão obscena da transparência diz respeito a um corpo sem referência, que não está direcionado, que não está em ação ou em situação. Um corpo torna-se obsceno quando é privado de toda narratividade, de todo direcionamento, de todo sentido. O obsceno é um fluxo que, em seu puro movimento, se coloca em aceleração por causa de si mesmo, de forma irracional e sem sentido, como uma manada. Essa aceleração apaga os tempos rituais, as suspensões contemplativas, tempos que não podem ser capturados e processados pela lógica da aceleração de forma homogênea. A igualdade é a condição imperativa de possibilidade da

\footnotetext{
7 Disponível em: https://www.stanforddaily.com/2020/06/01/please-let-students-turn-their-videos-off-inclass/. Acesso em: 25 abr. 2021.
}

$\begin{array}{llllll}\text { (C) ETD-Educação Temática Digital } & \text { Campinas, SP } & \text { v.24 } & \text { n.1 } & \text { p. } 53-70 & \text { jan./abr. } 2022\end{array}$


aceleração. Já a negatividade não apenas cunha experiência, como também o conhecimento subjetivo das suspensões particulares, das dimensões de contemplação.

É interessante fazer um breve desdobramento sobre as imagens resgatadas pelo filósofo sul-coreano a respeito da instância da intimidade dos espaços privados e públicos enquanto campos de performance. Nisso ele retoma aspectos que remetem ao contexto do distanciamento físico teatral. Han destaca a "distância cênica", que impede certo contato imediato entre corpos e almas. O teatral seria contraposto ao 'táctil', pois nele, através de formas e sinais rituais, comunica-se aquilo que pesa sobre a 'alma'. Na modernidade, renuncia-se cada vez mais à distância teatral em favor da intimidade. Na provocação de Han, hoje o mundo não é um teatro no qual são representados e lidos ações e sentimentos, mas uma vitrine de mercado onde estão expostas e são consumidas intimidades. Fazendo uma analogia, o teatro seria o lugar da 'representação'; o mercado, o local da 'exposição'. No lugar do caráter público, entra a publicização da pessoa. O público se transforma em espaço de exposição, afastando-se cada vez mais do espaço do agir comum. Nesse sentido, a sociedade da transparência é uma sociedade da informação, mas uma informação que está privada de qualquer negatividade; é uma linguagem positivada.

No meio das 'webaulas', das palestras online e dos cursos de capacitação, somos lançados à instância de produtores de conteúdo e de corrida por ressignificação pessoal. Assumimos outras performances. Mostramos nossas caras, nossas casas, construímos outras relações. Estreitamos intimidades em direção a uma escala de produtividade. Nesse movimento de constante exibição, aspectos caros, como a privacidade, são diluídos em favor da positividade e da abertura voluntária do foro íntimo enquanto moeda de troca da informação compartilhada nas múltiplas redes sociais. É necessário se exibir, colocar em disponibilidade sua individualidade em prol da transparência, que também assume um papel de controle e vigilância.

Se antes tínhamos uma ideia de sociedade disciplinar bastante alicerçada no pensamento de Michel Foucault (1987), na sociedade de controle do século XXI, o panóptico digital é perspectivístico, na medida em que não é mais vigiado por um centro. A distinção entre centro e periferia (fundamental para o conceito de panóptico de Jeremy Bentham refletido por Foucault) se perdeu. Hoje, a especificidade do panóptico digital é que seus habitantes digitais estão ligados em rede com intensiva comunicação entre si. $O$ que assegura o controle é a transparência, não o tradicional isolamento para a vigilância proposto por Bentham. A sociedade da transparência é uma sociedade da desconfiança e da suspeita, que, em virtude do desaparecimento da confiança, agarra-se ao controle, algo que aponta precisamente para o fato de que o fundamento moral da sociedade se tornou frágil e de que os valores morais de honestidade e sinceridade estão cada vez mais perdendo importância. 


\section{DISCURSO SOBRE MAIS TELAS E MAIS DINÂMICAS E O ESGOTAMENTO DAS VISIBILIDADES}

Toda essa dimensão da exposição toca em questões muito íntimas sobre como pensar a educação no campo subjetivo dos meios de produção neste período de suspensão. Os espaços da escola e da família são duas instâncias reconhecidamente relevantes para a formação sociocultural. São espaços cuja base é o processo de interação entre as diversas subjetividades e culturas que estão entre as fontes definidoras das relações humanas. No momento em que o ensino remoto, os distanciamentos e a educação em telas assumem um protagonismo pedagógico, é fundamental refletir sobre as implicações dessa nova lógica de interação na formação de professores, jovens e crianças na escola e nas famílias. A necessidade de atenção se desdobra sobre a mescla de entusiasmo frente à possibilidade de transformações da linguagem tecnológica e o avanço tão proclamado das metodologias e estratégias de ensino para a educação. O que vimos ao longo deste período de pandemia da covid-19 foi um euforia misturada a uma nova exposição da intimidade, provocada pela proliferação das redes sociais e por um aumento massivo dos usuários da internet, principalmente na centralidade do capitalismo e suas irradiações. A expansão da internet contribuiu para um período de explosão de produtividade e inovação, de redes sociais digitais, cibercultura, inteligência coletiva e reorganização da sociedade.

A possibilidade de se expressar para uma esfera global exacerbou grandes ambições, além de intensificar a promoção do 'você e eu' dentro dos novos circuitos digitais. Glorificase a menor das pequenezas, enquanto parece-se buscar a maior das grandezas. A proliferação de blogs e diários íntimos na primeira fase de expansão das redes sociais possibilitou o surgimento do que Paula Sibilia (2016) chama de "extimidade", que é a exteriorização intencional do foro íntimo a uma massa de pessoas com quem não se tem intimidade. Assim, o que poderia ser considerado possibilidade de inventividade acaba se transformando em consumo da metamorfose digital, devido à transformação dos modos de comunicação e das redes sociais.

As possibilidades abertas pelas novas formas de visibilidade e conectividade sem pausa lançam novos modos de estar no mundo. A combinação do 'faça você mesmo' com o 'mostre-se como for' agencia uma nova ruptura política, social, cultural e econômica, que implica a transformação e o surgimento de diferentes tipos de corpos, especialmente em plataformas como YouTube e Instagram. Nelas não são expostos os nossos esgotamentos em prol da vida virtual; há uma modulação da performance de comportamentos e hábitos de consumo. Trata-se de uma 'nova cultura', em que os usuários (agora vistos como potenciais clientes) viram o principal ativo de empresas e produtos.

Em meio a essa voracidade industrialista, teríamos atropelado as condições que permitiam a narratividade no mundo pré-moderno. Acabamos por nos encontrar em um

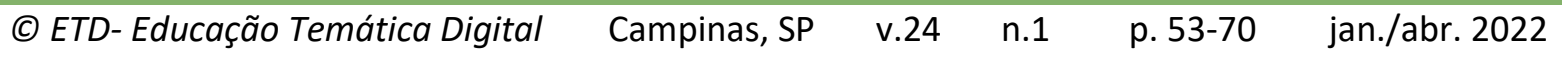


universo arrasado no frenesi das novidades com a enxurrada de dados que, em sua rapidez incessante, não se deixam digerir pela memória nem recriar lembrança. Toda essa agitação teria suscitado uma perda das possibilidades de refletir sobre o mundo, bem como um inevitável distanciamento com relação às próprias vivências e uma impossibilidade de transformá-las em experiência. Nossa funcionalidade multitarefa vai se desenvolvendo junto com a capacidade de nossos computadores, e, em algum momento, o esgotamento acaba por se estabelecer.

Em tempos em que impera um fluxo acelerado, a sedução (adaptada como necessidade de autoexposição) para que os sujeitos contemporâneos ajustem os principais eventos de suas vidas às exigências da câmera não surpreende. A espetacularização da vida cotidiana tornou-se habitual. Essa persona assumida da era digital acaba por nutrir uma cultura do individualismo, uma 'singularidade do eu' que a cada vez se torna mais atravessada pelos ditames identitários do mercado. Um risco cada vez mais tirânico da intimidade.

Cultuado e cultuado sem cessar, o Eu atual não demanda apenas atenção e cuidados; além disso, deve ser exposto da forma mais atraente possível para convocar sedentos olhares e conquistar todos os aplausos possíveis. (SIBILIA, 2016, p. 103)

Essa aceleração expositiva recai sobre uma instância de esgotamento das visibilidades e de culpabilização por não adequação ao uso das ferramentas. Nesse sentido, relatos de professores apontam para uma sensação de angústia quando se viram obrigados a lidar com as ferramentas digitais sem o mínimo de auxílio e/ou treinamento por parte de suas instituições. Entre o período de suspensão das atividades presenciais e a organização da instituição para o oferecimento de uma proposta de retorno às aulas no modo remoto, pouca estratégia pedagógica foi discutida sobre essa modificação. A solução apresentada foi uma mera transposição das rotinas presenciais para o meio da tela. As poucas inovações que foram vistas (e compartilhadas pelos professores e professoras ouvidos) foram buscadas por conta própria, um esforço por tentar trazer alguma dinamização às longas rotinas dos jovens frente às telas.

Em outro trabalho, Byung-Chul Han (2016) explora outra faceta contemporânea, um desdobramento da transparência e da velocidade, aquilo que seria a principal patologia do século XXI: a sociedade do cansaço. Uma sociedade que alimenta comportamentos como depressão, déficit de atenção, transtorno de Burnout, TDAH e demais sintomas que adentram nossa vivência. Nessa realidade, as sociedades do trabalho e do desempenho não seriam sociedades livres, uma vez que esses aspectos geram novas coerções, em que cada indivíduo 'carrega' consigo o seu campo de trabalho e, junto a isso, outros regimes, para além dos disciplinares. Como já apontamos neste texto, Han (2017) considera que a sociedade do século XXI não é mais a sociedade disciplinar, no estilo foucaultiano, mas uma sociedade do desempenho.

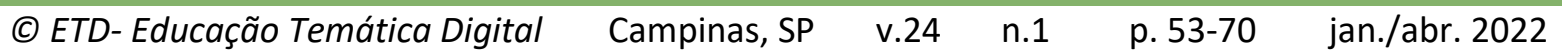


A sociedade disciplinar é uma sociedade da negatividade. Ela é determinada pela negatividade da proibição. O verbo modal negativo que a domina é o "não-ter-o-direito". A sociedade do desempenho, por sua vez, vai se desvinculando cada vez mais da negatividade: em lugar da proibição, entram o projeto, a iniciativa e a motivação. Hoje são as academias, os escritórios, os bancos, os aeroportos, os shoppings e outros dispositivos valorizadores do desempenho que ganham o destaque das antigas instituições disciplinares. Os sujeitos dessa sociedade não se chamam mais "sujeitos da obediência", mas "sujeitos de desempenho e produção", ou, como é propagado pela sociedade neoliberal: empresários de si mesmos, cada vez mais rápidos, mais produtivos que os sujeitos obedientes da sociedade disciplinar.

O poder ilimitado é o verbo modal positivo da sociedade de desempenho. O plural coletivo da afirmação Yes, we can expressa precisamente o caráter de positividade da sociedade de desempenho. No lugar de proibição, mandamento ou lei, entram projeto, iniciativa e motivação. A sociedade disciplinar ainda está dominada pelo não. Sua negatividade gera loucos e delinquentes. A sociedade do desempenho, ao contrário, produz depressivos e fracassados. (HAN, 2016, p. 24-25)

É neste contexto de pandemia e de ensino remoto, no qual a proatividade e a desenvoltura frente às tecnologias e visualidades empurram, em nosso caso, o fazer docente a acoplar cada vez mais habilidades e iniciativas que temos como resultado carreiras deprimidas. Elas são agravadas por esse outro modelo disciplinar de controle comportamental que, autoritária e proibitivamente, estabelece seu papel às classes sociais. É através dessa "economia do si-mesmo" que nos tornamos deprimidos.

Vamos percebendo, cada vez mais, que o que causa a depressão do esgotamento não é o imperativo de obedecer apenas a si mesmo, mas também a "pressão por desempenho". Han (2016) aponta que o homem depressivo é aquele animal laborans que explora a si mesmo, e quiçá deliberadamente, sem qualquer coação estranha. É agressor e vítima ao mesmo tempo. É um escravo das multitarefas. O animal laborans pós-moderno não abandona sua individualidade ou seu ego para entregar-se pelo trabalho a um processo de vida anônima da espécie. Ao contrário, a sociedade laboral individualizou-se numa sociedade de desempenho e numa sociedade ativa. O animal laborans pós-moderno é provido do ego ao ponto de quase dilacerar-se. 


\section{O QUE É POSSÍVEl VER PARA ALÉM DA EXIBIÇÃO: PELO DIREITO DE UM OUTRO OLHAR}

É por meio do excesso de positividade e de desempenho (que se manifesta também como excesso de estímulos, informações e impulsos) que são modificadas as estruturas e a economia da atenção, destruindo-as. Somos soterrados pela sobrecarga do trabalho cada vez mais automatizado, por tempos cada vez mais fluidos e indeterminados. Nesse processo de dilaceramento, vamos abandonando 'docilmente' os breves momentos de contemplação, lazer e poesia. Há um conflito de estado contemplativo versus tédio (que implica uma necessidade constante de movimento). Se, no estado contemplativo, somos provocados a sair de nós mesmos, mergulhando na poesia das coisas, hoje em dia cada vez mais as temporalidades da imagem são aceleradas. Os estímulos são pulsantes e elétricos. Os aplicativos de realização de vídeos, cada vez mais curtos, cheios de efeitos, expostos, efêmeros. A autoexposição é um imperativo.

Em meio ao contexto apresentado de exaustão, cansaço e velocidade das telas, é possível pensar alternativas para articular uma retomada da vida contemplativa no espaço de aprendizagem virtual por meio de uma pedagogia específica do ver; experimentar uma oportunidade para usar essas telas enquanto possibilidade de abertura de outras janelas. Para isso, há a necessidade de um 'outro ver', que reabitue o olho ao descanso, à paciência, ao deixar-se aproximar-se-de-si, que permita capacitar o olhar a uma atenção profunda e contemplativa, um olhar demorado e lento. É preciso aprender a não reagir imediatamente a um estímulo, mas tomar controle dele. Mas, no fim das contas, há possibilidade de [re]existir dentro de uma sociedade do fracasso? Optar por se deslocar dessa lógica seria realmente um fracasso? Como poderíamos pensar linhas de fuga dentro desse processo? Uma forma de pensar é agenciar outras imagens por meio do cinema e da produção audiovisual, usufruindo do espaço privilegiado da escola.

Nesse sentido, é preciso resgatar outras formas de ver as imagens, como ensina o poeta Manoel de Barros quando diz que "O olho vê, a lembrança revê e a imaginação transvê. É preciso transver o mundo" (BARROS, 2008, p. 75). Pôr a atenção, a memória e a imaginação em cena. Quando propomos pensar a presença dos filmes na escola, tentamos fazê-lo atravessando esse movimento que nos ensina o poeta. Em um primeiro movimento, o expectador busca ver e ouvir. Depois, é preciso rever, prestando muita atenção, tentando lembrar tudo aquilo que não vimos ou ouvimos na primeira vez. Na terceira vez, tentamos imaginar outras possibilidades para essas imagens. Dessa forma, nos habituamos a vê-las de um modo menos acabado, menos determinado. Olhar para elas como se ainda pudéssemos inventar algo a partir delas ou em seu lugar, aquilo que Alain Bergala (2002) denomina "análise criativa dos filmes". O cinema na escola fomenta um olhar para o conhecimento do

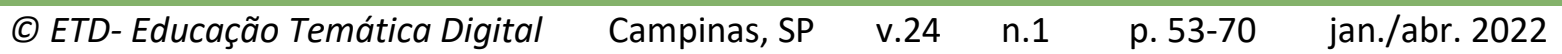


mundo por descoberta e invenção a partir das imagens, logo o hábito contamina todas as formas de olhar para o mundo, a realidade social, as relações humanas, os saberes escolares.

Tão importante quanto a forma e a abordagem do cinema dentro do currículo escolar é experimentar ver e fazer imagens. Este é um ponto fundamental: refletir sobre a nossa relação com as imagens, principalmente neste contexto pandêmico. Efetivamente, a quarentena extrapolou largamente os quarenta dias. Já abordamos neste texto as dimensões de transparência e das imagens pornográficas, da hiperexposição em contraste à dimensão opaca, velada das imagens. Mas seria possível pensar um espaço dentro do ensino remoto para pensarmos a experimentação audiovisual de imagens opacas? Isto é, realizar exercícios que fossem para além das 'garrafas virtuais' postadas nas redes sociais, na tentativa de produzir efetivas estratégias de diálogo entre estudantes, compartilhando algo do cotidiano dessas vidas?

Em meio ao contexto educacional pandêmico, algumas alternativas estão sendo desenvolvidas por professores em situação de ensino remoto ${ }^{8}$. As iniciativas desses docentes propõem a realização de filmes e pequenos experimentos estéticos por meio do celular junto a seus alunos durante a pandemia. A premissa é permitir uma experiência estética de realização de imagens criativas e poéticas pelos jovens, bem como problematizar os novos contornos da hiperexposição das visibilidades. A todo tempo, estamos sendo filmados nos diferentes estabelecimentos por onde circulamos, inclusive nas escolas, que, muitas vezes, socializam com os pais imagens ao vivo das atividades desenvolvidas pelos estudantes durante o período escolar nas aulas online. É fundamental, portanto, refletirmos juntos sobre os limites e a ética de filmar. Ver e dar a ver é uma questão que merece um cuidado especial e é preciso explicitar e explanar isso em toda situação de produção audiovisual escolar.

No primeiro momento deste texto, buscamos compartilhar algumas reflexões sobre o impacto do contexto de pandemia tanto na esfera social quanto docente, principalmente no que diz respeito à reflexão sobre a exposição dos espaços domésticos e a saturação da hiperexposição das imagens. Nesse sentido, uma possibilidade que surgiu das experimentações de professoras junto aos seus alunos (na busca pela diversificação dos usos das tecnologias e da saturação da claridade das telas) foi o uso do celular para produzir pequenos vídeos, como pequenas cartas audiovisuais da pandemia, ou, como um dos alunos comentou em uma das aulas remotas: 'videocartas pandêmicas'.

\footnotetext{
${ }^{8}$ Essas experimentações foram compartilhadas em grupos de pesquisa, de extensão e em fóruns de compartilhamento das experiências docentes durante a pandemia.
}

$\begin{array}{llllll}\text { (C) ETD-Educação Temática Digital } & \text { Campinas, SP } & \text { v.24 } & \text { n.1 } & \text { p. } 53-70 & \text { jan./abr. } 2022\end{array}$ 
Essa experiência ${ }^{9}$ foi proposta por uma professora de produção de textos dos anos finais do ensino fundamental de uma escola que pertence a uma rede de ensino da região metropolitana de Belo Horizonte-MG. Essa proposta experimental aconteceu de forma prática em algumas aulas, equanto a professora buscava alternativas para articular de forma crítica e sensível a relação e a presença dos corpos nas aulas remotas. O processo de produção consistia em um convite para que os alunos que quisessem produzissem vídeos curtos, de até três minutos, mostrando imagens, objetos, rotinas, histórias ou momentos que, na visão deles, seriam ilustrativos de uma emoção e/ou reflexão sobre estes tempos de distanciamento.

A ideia de abrir um espaço para conversar sobre isso com os alunos começou quando a professora percebeu a falta de ânimo de suas turmas durante as longas jornadas diárias em frente ao computador nas aulas remotas e o iminente risco de depressão e ansiedade (LINHARES; ENUMO, 2020). Por conta das múltiplas janelas, são muitos os alunos que se distraem com a presença dos demais colegas, perdem o foco ou até chegam a sentir uma sensação de vigilância. Como comentamos anteriormente, o atravessamento dos espaços da escola e da casa é muito sensível no contexto de ensino remoto. A relação pedagógica que antes era estabelecida entre professores e alunos no espaço da sala de aula agora é atravessada pelo olhar de pais e outros familiares.

Assim, para promover uma suspensão da rotina de aulas online, a professora iniciou uma experiência estética junto às suas turmas. Ela passou a dedicar cerca de dez a vinte minutos de uma de suas aulas semanais para aqueles alunos que quisessem compartilhar suas percepções sobre este momento na vida deles. O espaço era aberto e se manifestava quem quisesse. Em meio às respostas, surgiam angústias, saudades dos colegas, da escola, do tato das pessoas. Foi por conta desses relatos que a professora cogitou a ideia de sugerir à turma que os alunos registrassem imagens que representassem esses sentimentos. Alguns deles produziram planos poéticos de janelas: "Do mundo lá fora da janela" (desejando retornar ao convívio com os colegas). Outros vídeos apresentavam fragmentos da rotina dos pais dentro de suas casas. Já outros elaboraram montagens no estilo videoclipe, compartilhando impressões em forma de texto narrado. Houve também aqueles que produziram narrativas do cotidiano fortemente pautadas pelas falhas e limitações tecnológicas.

É interessante destacar um elemento que atravessa a maior parte dos vídeos que foram produzidos: a ausência do autorretrato (ou de planos cuja presença do aluno-cineasta se faça presente). Em alguns momentos, os olhares aparecem fugidios ou nos reflexos de

\footnotetext{
${ }^{9} \mathrm{O}$ relato aqui apresentado foi desenvolvido de maneira experimental por uma professora durante o primeiro semestre do ano de 2021. Infelizmente, durante o tempo de análise da publicação deste artigo, o projeto foi interrompido precocemente, devido ao seu desligamento da instituição. Esse acontecimento inviabilizou a negociação do uso, para este artigo, das primeiras imagens produzidas pelos alunos.
}

$\begin{array}{llllll}\text { (C) ETD-Educação Temática Digital } & \text { Campinas, SP } & \text { v.24 } & \text { n.1 } & \text { p. } 53-70 & \text { jan./abr. } 2022\end{array}$ 
superfícies opacas, como portas metalizadas, telas pretas de celulares e computadores. Os temas mais presentes foram os pontos de vista de situações contemplativas com som ambiente (em alguns casos, o registro sonoro dos vídeos apresenta o contexto dos ruídos constantes de obras, máquinas, conversas etc. que viraram a paisagem sonora constante dos momentos de estudo e aulas virtuais dos jovens).

Ao analisar essas produções, identificamos que a professora mineira consegue tensionar vários aspectos que Han $(2016,2017)$ aponta. Os trabalhos audiovisuais, em alguma medida, parecem resistir à hegemonia da positividade da "sociedade da transparência" (HAN, 2017), pois dribla certa imposição/disposição da abertura e horizontalidade das funções sociais e subjetivas, alinhando-se às singularidades, ao fosco do cotidiano pouco ideal e bem sucedido. Há um espaço para a negatividade, para o compartilhamento de um tempo de sofrimento e isolamento inédito. Trata-se de imagens que não podemos identificar como informação ou comunicação, elas traduzem um espaço e um tempo em suspensão quase inominável, pressupõem um tipo de interação que vira pelo avesso os frequentes formatos tutoriais (FRAGA et al., 2021).

Outro aspecto que emerge tem relação com a opacidade de um tempo que tem como principal destino o evento interativo do compartilhamento sensível das vidas neste tempo singular. A professora articula uma mediação entre a produção e a exibição das imagens produzidas que foge à homogeneização dos fluxos de imagens que rolam para abaixo sem fim no ato de avançar scroll down no aplicativo de qualquer rede social. A diferença entre a exposição do íntimo de qualquer sala virtual é que, nesse caso, houve um convite e cada participante escolheu exatamente o que desejava compartilhar, apenas se desejasse.

Ainda sobre essa tirania da visibilidade que alcança as aulas, nas cartas audiovisuais pandêmicas isso fica tensionado pelo destaque dos sons. Mesmo em se tratando de sons ambiente, pelo fato de os enquadramentos terem sido fundamentalmente contemplativos, a atenção é desviada para os sons, que ganham protagonismo. Se a visibilidade é tudo o que a sociedade do espetáculo aponta, aqui, a "coação icônica" para tornar-se "imagem" acaba sendo desviada para o sonoro - e sabemos que os sons chegam primeiro ao nosso interior (BRESSON, 2005). Assim, outra comunicação parece possível.

O fato de as 'videocartas pandêmicas' não trazerem imagens dos próprios realizadores traz mais uma curiosidade interessante para a reflexão, contradizendo, nesse caso, o comportamento dos corpos nesse processo de coação para tornar-se imagem, assumir-se protagonista. O "show do eu" (SIBILIA, 2016) é esquivado pela alteridade das janelas, dos espaços do lar e das outras pessoas que habitam a casa. Os processos de desaceleração que resultam de uma proposta que orienta estudantes a olhar para o familiar procurando um fragmento para compartilhar parecem constituir uma alternativa aos fluxos de produção aleatória de imagens e à velocidade de compartilhamento. Esses fluxos de produção e essa

$\begin{array}{llllll}\text { (C) ETD-Educação Temática Digital } & \text { Campinas, SP } & \text { v.24 } & \text { n.1 } & \text { p. 53-70 } & \text { jan./abr. } 2022\end{array}$


velocidade levam as pessoas (espectadores-produtores) à exaustão. Há, nesse movimento, uma pedagogia indiscutível e indecifrável, que ainda iremos desvendar com o passar dos anos.

Além da produção dos vídeos, a professora buscava apresentar curta-metragens ${ }^{10}$ que promovessem um olhar estético-criativo da turma, trazendo uma diversidade de visualidades. A proposta era de que, conforme a turma fosse criando intimidade com essa linguagem, os estudantes passassem a compartilhar essas 'videocartas pandêmicas' com outros colegas e, quem sabe, montassem uma página virtual em que estudantes de outras escolas pudessem enriquecer esse diário audiovisual. Mesmo com a interrupção do projeto, é importante destacar que o engajamento da turma foi bastante entusiasmado e que bons frutos ainda são aguardados.

Para finalizar, esperamos que novas práticas e experiências com outros usos dos recursos tecnológicos propagados possam capturar e ampliar o sentido das que aqui se apresentam e realizar imagens e percepções sobre o momento dos alunos em processo de ensino remoto em um fecundo diálogo. Uma experiência audiovisual que contamine a escola toda. Imagens que possam dialogar com múltiplos olhares, que provoquem diferentes pensamentos, afetividades e sensações de uma vez só, tensionando dúvidas e certezas, sendo também uma produção que ocupe um lugar entre as linguagens artísticas, mas sem nos esquecermos de que se trata de uma arte que é mídia, ou de uma mídia que é arte, e que ainda se encontra privilegiada pelas múltiplas linguagens que a habitam e pela possibilidade de vir a qualificar esse duplo papel que todos e todas exercemos como receptores e produtores, de modo cada vez mais consciente e sensível. Vamos fazer fazendo.

\section{REFERÊNCIAS}

AGAMBEN, Giorgio. Reflexões sobre a peste. São Paulo: Boitempo, 2020.

BARROS, Manoel. Livro sobre nada. Rio de Janeiro/São Paulo: Record, 2008.

BERGALA, Alain. L'hipothèse cinéma: Petit traité de transmission du cinema à l'école et ailleurs. Paris: Petit Bibliothèque des Cahiers du Cinéma, 2002.

BRESSON, Robert. Notas sobre o cinematógrafo. São Paulo: lluminuras, 2005

CRARY, Jonathan. 24/7: Capitalismo tardio e os fins do sono. São Paulo: UBU, 2016.

FOUCAULT, Michel. Vigiar e Punir: Nascimento da Prisão. Petrópolis: Editora Vozes, 1987.

\footnotetext{
10 Uma das referências utilizadas pela professora para compartilhar possibilidades visuais de realização com as turmas foram os vídeos do projeto "Inventar com a Diferença: cinema e direitos humanos", que estão disponíveis no portal https://vimeo.com/inventarcomadiferenca. Acesso em: 10 abr. 2021.
}

$\begin{array}{llllll}\text { (C) ETD-Educação Temática Digital } & \text { Campinas, SP } & \text { v.24 } & \text { n.1 } & \text { p. } 53-70 & \text { jan./abr. } 2022\end{array}$ 
FRAGA, Nuno; PEREIRA, Gorete; GOUVEIA, Fernanda; GOUVEIA, Ana Isabel. Educação em tempos de COVID-19: o acesso condicionado à aprendizagem. Um estudo exploratório numa escola em Portugal. Sensos-E, v. 8, n. 1, p. 77-87, 2021. Disponível em: https://doi.org/10.34630/sensose.v8i1.3786. Acesso em: 25 maio 2021.

HAN, Byung-Chul. Sociedade do cansaço. Petrópolis: Editora Vozes, 2016.

HAN, Byung-Chul. Sociedade da transparência. Petrópolis: Editora Vozes, 2017.

HARARI, Yuval Noah. Notas sobre a pandemia: e breves lições para o mundo póscoronavírus. São Paulo: Companhia das Letras, 2020.

LINHARES, Maria Beatriz Martins; ENUMO, Sônia Regina Fiorim. Reflexões baseadas na Psicologia sobre efeitos da pandemia COVID-19 no desenvolvimento infantil. Estudos de Psicologia, Campinas, online, v. 37, p. 1-14, 2020, Disponível em:

https://doi.org/10.1590/1982-0275202037e200089. Acesso em: 20 abr. 2021.

NICANDRO, Vincent; KHANDELWAL, Aditya; WEITZMAN, Alex. Please, let students turn their videos off in class. The Stanford Daily, 10 jun. 2020. Disponível em:

https://www.stanforddaily.com/2020/06/01/please-let-students-turn-their-videos-off-inclass/. Acesso em: 25 abr. 2021.

SIBILIA, Paula. O Show do Eu: A intimidade como espetáculo. Rio de Janeiro: Editora Contraponto, 2016.

ZIZEK, Slavoj. Pandemia: Covid-19 e a reinvenção do comunismo. São Paulo: Boitempo, 2020.

Revisão gramatical realizada por: Isadora Bonfim Nuto.

E-mail: isadorabnuto.unb@gmail.com 